\title{
The Impact of Terrorism on Capital Markets
}

\author{
GUALTER COUTO \\ School of Business and Economics, University of Azores and CEEAplA \\ 9500-321 Ponta Delgada \\ PORTUGAL \\ PEDRO PIMENTEL \\ School of Business and Economics, University of Azores and CEEAplA \\ 9500-321 Ponta Delgada \\ PORTUGAL
}

CARINA ROIAS

School of Business and Economics, University of the Azores

9500-321 Ponta Delgada

PORTUGAL

RUI ALEXANDRE CASTANHO

Faculty of Applied Sciences, WSB University

41-300 Dabrowa Górnicza

POLAND

and

College of Business and Economics, University of Johannesburg

PO Box 524, Auckland Park

SOUTH AFRICA

Abstract: This work aims to analyze the impact of terrorism on the countries' capital markets and in the transport industry. To this end, eight recent terrorist attacks in the European Union have been studied and compared to two older similar attacks in the same region. The stock indices used in this study relate to the country's main index where the attack occurred and the FTSE Euro 100, S\&P 500, and Dow Jones Singapore indices, representing the European, American, and Asian markets respectively. The results of this work are relatively discrepant since it was not possible to identify concretely the pattern of a terrorist attack on the capital markets. However, when we look at both time horizons studied, the results point to a greater capacity for market recover over time on terrorism.

Key-Words: Stock Indices; Terrorism; Event Study; Abnormal Returns; Capital Markets; Resilience

Received: November 20, 2020. Revised: May 14, 2021. Accepted: May 25, 2021. Published: June 2, 2021.

\section{Introduction}

Terrorism is a rare but too violent phenomenon, unpredictable and with a very significant potential for destruction. Since the 1960s, terrorist attacks have been occurring more frequently. In Europe, the deadliest attack occurred in Spain in 2004.
Terrorism is thus responsible for several consequences. The direct consequences of terrorism include loss of life and destruction of property, emergency response, restoration of affected systems and infrastructures, and the provision of temporary life assistance, which costs are usually associated with a short period [1]. However, terrorism has 
other significant indirect consequences, such as interference with investor confidence [2] and the rising costs of counter-terrorism policies [3]. According to Enders and Olson [4], the indirect costs arising from terrorist attacks are the most difficult ones to quantify and are regarded as longterm costs because they persist until terrorists cease their activity [3].

As Becker and Rubinstein [5] mentioned, any terrorist attack generates an adverse reaction from the financial markets. Following this initial negative effect caused by high levels of uncertainty, it is necessary to assess the long-term impact of the crisis and markets' timing to return to their pre-crisis state [6].

Using the event study methodology, Chen and Siems [7] analyzed the impact of 14 terrorist attacks or military invasions on the US stock market. They concluded that terrorist attacks and military invasions could affect capital markets worldwide over a short period. The US capital market has become increasingly able to overcome the shock caused by terrorism [7]. Ferguson [8] states that, on September 11, the US Federal Reserve ensured that the payment system was not interrupted by providing the necessary liquidity to the markets allowing them to return to regular operation quickly and effectively.

Other studies analyze the impact of terrorism on specific industries. Industries like airlines, hospitality, and entertainment are negatively affected by certain events, as shown by Cam [9] after September 11. However, as investors look for stable investments, some markets may show positive results, as shown in a study of 24 international defense companies conducted by Apergis and Apergis [10]. Considering the attack occurred in Paris in November 2015, their results suggested that investors were expecting new attacks, preferring stocks from the defense industry (given their importance in fighting terrorism). More recently, Aliyev [11] focus on the terrorism role in a whole country tourism development strategy. Bonekamp and Veen [12] analysed several attacks, namely that of New York (2001), Madrid (2004), London (2005), Boston (2013), Paris (2015), Brussels (2016), Nice (2016) and Berlin (2016). The results are not consistent across attacks, but show that the impact, if any, is relatively small and brief.

\section{Methodology}

The event study methodology's main objective is to evaluate the impact of an event on the profitability of a stock or index by identifying abnormal returns obtained following that event [13]. Any particular event generates a favorable or unfavorable reaction among investors, giving rise to abnormal positive or negative returns [7]. Thus, analyzing abnormal returns in various indices is a means of assessing a particular sector's response or capital market to a specific event [13].

The basis of the event study methodology is the efficient market hypothesis, presented by Fama et al. [13]. This hypothesis reveals that, as new information becomes known to the market (such as a terrorist attack), it is weighted by investors who assess its current and future impact, generating changes in prices. According to Schwert [14], the strength of the methodology in question lies in its ability to identify abnormal changes since it is based on the global assessment of many investors who quickly process all available information to assess the market value of each individual stock. In addition, the results of this methodology are easy to interpret, thus allowing its sharing.

However, there are some limitations associated with the event study methodology. First, it depends on the assumption of an efficient market, and this assumption is not valid in many situations. Markets may show inefficiencies as stock prices do not instantly reflect the information available. However, this fact can be partially overcome by analysing the cumulative abnormal returns (CAR's). The methodology used is also limited by the fact that it does not consider other effects that do not result from the event. For example, simultaneous events can weaken or reinforce the results of the specific event of interest. In addition, the results generated from this methodology are very sensitive to changes in the parameters of the investigation, such as, for example, the alteration of the estimation windows.

According to Campbell et al. [15], the event study methodology does not have a fixed structure. However, the authors describe that its analysis can consist of seven steps, that includes the definition of the event: its date of occurrence (date zero); the period under analysis (event window); the criteria used to select the sample and for measuring normal and abnormal returns, the estimation and testing procedure and, finally, presenting and interpreting the empirical results.

In this case, the events we considered were terrorist attacks in the European Union between 2015 and 2017, which effectively resulted in 8 or more fatalities (time horizon 1) and the attacks occurred in Madrid and London, on 11 March 2004 
and 7 July 2005, respectively (time horizon 2). We considered two event windows corresponding to 5and 10-day periods after the event to understand how quickly the market absorbed the news. We will use both the daily data of the affected country's main index, the domestic index, and data from three other stock indices (FTSE Euro 100 Index, S\&P 500, and Dow Jones Singapore, respectively). We will also analyze the influence of terrorist attacks on the transport sector by using the Dow Jones Transportation Average Index because many of the attacks targeted transport.

This database will thus allow us to calculate continuous daily returns using a logarithmic calculation formula (equation 1 ). In equation $1, \mathrm{Rjt}$ represents the normal returns, Pt corresponds to the price of the index $\mathrm{j}$ in the period $\mathrm{t}$ and Pjt-1 corresponds to the price of index $\mathrm{j}$ on the day before t.

$$
R_{j t}=\ln \left(\frac{P_{j t}}{P_{j t-1}}\right)
$$

The abnormal returns for the day of the event and the event windows (Ajt) were calculated according to the mean-adjusted returns model (constant), represented in equation 2.

$$
A_{j t}=R_{j t}-\bar{R}_{j}
$$

The mean $\mathrm{Rj}$ component is calculated according to equation 3 . In this calculation we considered a 20-day estimation window from $t=-30$ to $t=-11$ in relation to the date of the event $(t=0)$.

$$
\bar{R}_{j}=\frac{1}{20} \sum_{t=-30}^{-11} R_{j t}
$$

Concerning the aforementioned event windows, $(\mathrm{t}=+5$ and $\mathrm{t}=+10)$, we also calculated the cumulative abnormal returns (CAR's). These values are obtained using the following equation:

$$
C A R_{t}=\sum_{t} A_{j t}
$$

After making all the above calculations, we used the statistical tests described by Brown and Warner [16] to evaluate the statistical significance of abnormal returns. Thus, this study tests the following two research hypotheses for each event:
H10: The abnormal return of the day of the event is zero, meaning that there was no immediate impact of the event on the indices under study.

H11: The abnormal return of the day of the event is not zero.

$\mathrm{H} 20$ : The cumulative abnormal returns for the two event windows are zero, meaning that there was no subsequent impact of the event on the indices under study.

H21: The cumulative abnormal returns for the two event windows are not zero.

The rejection of $\mathrm{HO}$ indicates that abnormal returns (or cumulative abnormal returns) were not equal to zero, meaning that they had an impact on a particular event or index.

Furthermore, in this study we will compare the two-time horizons, the first of which concerns the attacks in Madrid and London (March 11, 2004, and July 7, 2005, respectively) and the second concerning the other attacks previously mentioned. This will allow us to evaluate the resilience of the markets over time. To do this, we will use the average obtained using the cross-sections for each time horizon. So, the following equation is applied to calculate the average abnormal returns of the day of the event (AARt), where $t$ is 0 :

$$
A A R_{t}=\frac{1}{N} \sum_{i=1}^{N} A R_{i, t}
$$

The cumulative average abnormal returns (CAARt) for the two event windows under study $(\mathrm{t}=+5$ and $\mathrm{t}=+10)$ are calculated according to equation 6 .

$$
C A A R_{t}=\frac{1}{N} \sum_{i=1}^{N} C A R_{i, t}
$$

After the above ${ }^{i=1}$ calculations, we can move on to the statistical significance tests for each time horizon:

$\mathrm{H} 30$ : The average abnormal return of the day of the event is zero, meaning that there was no immediate impact of the event on the indices under study.

H31: The average abnormal return of the day of the events is not zero.

H40: The cumulative average abnormal returns for the two event windows are zero, meaning that there was no subsequent impact of the event on the indices under study.

H41: The cumulative average abnormal returns for the two event windows are not zero. 


\section{Empirical Results}

To effectively assess the impact of an attack on a given index, we must analyze abnormal returns. Table 1 shows the values of the abnormal returns associated with the event's day for the different indices and the events under analysis.

Table 1: Abnormal returns on the day of the event $(\mathrm{t}=0)$

\begin{tabular}{|c|c|c|c|c|}
\hline Events & $\begin{array}{l}\text { Domestic } \\
\text { Index }\end{array}$ & $\begin{array}{l}\text { FTSE } \\
\text { EURO } \\
100 \\
\end{array}$ & S\&P 500 & $\begin{array}{l}\text { Dow } \\
\text { Jones } \\
\text { Singapore }\end{array}$ \\
\hline \multirow{2}{*}{$\begin{array}{l}\text { Spain, } \\
11 / 03 / 2004\end{array}$} & $\overline{2} .236 \% * * *$ & $2.859 \%$ *** & $-1.604 \%$ ** & $-1.142 \%$ \\
\hline & $(-2.892)$ & $(-3.732)$ & $(-2.715)$ & $(-1.493)$ \\
\hline \multirow{2}{*}{$\begin{array}{l}\text { England, } \\
07 / 07 / 2005\end{array}$} & $1.506 \% * * *$ & $\begin{array}{l}- \\
1.856 \% * * *\end{array}$ & $0.140 \%$ & $-0.004 \%$ \\
\hline & $(-3.349)$ & $(-3.228)$ & -0.352 & $(-0.009)$ \\
\hline \multirow{2}{*}{$\begin{array}{l}\text { France, } \\
07 / 01 / 2015\end{array}$} & $0.695 \%$ & $0.465 \%$ & $-0.915 \%$ & $0.958 \%$ \\
\hline & $(-0.415)$ & $(0.278)$ & $(-0.902)$ & $(1.703)$ \\
\hline \multirow{2}{*}{$\begin{array}{l}\text { France, } \\
13 / 11 / 2015\end{array}$} & $-0.545 \%$ & $-0.445 \%$ & $1.162 \%$ & $0.084 \%$ \\
\hline & $(-0.457)$ & $(-0.402)$ & -1.467 & $(-0.087)$ \\
\hline \multirow{2}{*}{$\begin{array}{l}\text { Belgium, } \\
22 / 03 / 2016\end{array}$} & $-0.145 \%$ & $-0.304 \%$ & $-0.969 \%$ & $-1.098 \%$ \\
\hline & $(-0.095)$ & $(-0.170)$ & $(-0.906)$ & $(-1.083)$ \\
\hline \multirow{2}{*}{$\begin{array}{l}\text { France, } \\
14 / 07 / 2016\end{array}$} & $-0.034 \%$ & $0.121 \%$ & $-0.078 \%$ & $0.451 \%$ \\
\hline & $(-0.014)$ & $(-0.048)$ & $(-0.063)$ & $(-0.499)$ \\
\hline \multirow{2}{*}{$\begin{array}{l}\text { Germany, } \\
19 / 12 / 2016\end{array}$} & $0.314 \%$ & $0.560 \%$ & $0.185 \%$ & $-0.197 \%$ \\
\hline & $(-0.527)$ & $(-0.943)$ & $(-0.436)$ & $(-0.389)$ \\
\hline \multirow{2}{*}{$\begin{array}{l}\text { England, } \\
22 / 05 / 2017\end{array}$} & $-0.283 \%$ & $0.256 \%$ & $0.427 \%$ & $0.125 \%$ \\
\hline & $(-0.456)$ & $(-0.256)$ & $(-0.954)$ & $(-0.315)$ \\
\hline \multirow{2}{*}{$\begin{array}{l}\text { England, } \\
\text { 03/06/2017 }\end{array}$} & $-0.531 \%$ & $0.446 \%$ & $-0.143 \%$ & $-0.277 \%$ \\
\hline & $(-0.819)$ & $(-0.439)$ & $(-0.260)$ & $(-0.712)$ \\
\hline \multirow{2}{*}{$\begin{array}{l}\text { Spain, } \\
17 / 08 / 2017\end{array}$} & $-0.582 \%$ & $-0.461 \%$ & $1.647 \%$ *** & $-0.605 \%$ \\
\hline & $(-0.868)$ & $(-0.701)$ & $(-4.629)$ & $(-1.072)$ \\
\hline
\end{tabular}

*Statistically significant at $10 \%$; (Test values in parentheses); ${ }^{* * *}$ Statistically significant at $5 \%$; ${ }^{* * * *}$ Statistically significant at $1 \%$

Our research within the topic under study shows that terrorist attacks usually harm stock market indices. Table 1 shows that more than $60 \%$ of returns under analysis are negative, thus being in line with the literature. However, we only found statistically significant results in three events (Spain, March 11, 2014); England, July 7, 2005; Spain, August 17, 2017). In Spain's attack in 2004, all abnormal returns are harmful, and only the Asian index value is not statistically significant. Therefore, we reject the null hypothesis for all three indices, concluding that this event harmed both the IBEX 35 index and the indices representing the European and American markets. There is a strong indication that the attack mentioned above was responsible for a negative impact on a virtually global level since it caused significant changes in indices from different parts of the world.

In the 2005 attack in England, negative abnormal returns were significant at $1 \%$ significance only in the domestic FTSE 100 index and the European index (FTSE Euro 100). We conclude that, probably, the attack only harmed the European continent. This may have to do with London's position as the financial center of Europe.

Contrary to expectations, the attack in France on November 13, 2015, did not lead to the emergence of any significant returns in the indices. The assumption is made that, since it occurred over the weekend, it did not significantly impact the indices because investors had more time to react to the event's effects.

Finally, Spain's attack on August 17, 2017, generated a significant $1 \%$ negative return on the US index. All the other results show that the attacks did not affect the indices since the returns are negligible.

The date of the event, which was analyzed beforehand, represents the investors' immediate reaction. However, to determine whether the attacks had a lasting effect on the markets, we should consider cumulative abnormal returns (CARs). This allows assessing the investors' reactions over time. Concerning 6-day cumulative abnormal returns (6day CARs), we found that $67.5 \%$ of the results are negative, as shown in Table 2.

Table 2: 6-day cumulative abnormal returns $(\mathrm{t}=+5)$

\begin{tabular}{|c|c|c|c|c|}
\hline Events & $\begin{array}{l}\text { Domestic } \\
\text { Index }\end{array}$ & $\begin{array}{l}\text { FTSE } \\
\text { EURO } \\
100\end{array}$ & $\begin{array}{l}\text { S\&P } \\
500\end{array}$ & $\begin{array}{l}\text { Dow } \\
\text { Jones } \\
\text { Singapore }\end{array}$ \\
\hline \multirow{2}{*}{$\begin{array}{l}\text { Spain, } \\
11 / 03 / 2004\end{array}$} & $-\overline{6.077 \% * * *}$ & $-4.987 \% * *$ & $-0.364 \%$ & $-2.075 \%$ \\
\hline & $(-3.209)$ & $(-2.658)$ & $(-0.252)$ & $(-1.107)$ \\
\hline \multirow{2}{*}{$\begin{array}{l}\text { England, } \\
07 / 07 / 2005\end{array}$} & $-0.228 \%$ & $0.384 \%$ & $1.980 \% *$ & $0.799 \%$ \\
\hline & $(-0.207)$ & $(-0.273)$ & $(-2.025)$ & $(-0.716)$ \\
\hline \multirow{2}{*}{$\begin{array}{l}\text { France, } \\
07 / 01 / 2015\end{array}$} & $3.257 \%$ & $2.286 \%$ & $-0.009 \%$ & $-0.293 \%$ \\
\hline & $(-0.794)$ & $(-0.558)$ & $(-0.004)$ & $(-0.213)$ \\
\hline \multirow{2}{*}{$\begin{array}{l}\text { France, } \\
13 / 11 / 2015\end{array}$} & $-1.142 \%$ & $-0.447 \%$ & $1.187 \%$ & $-2.544 \%$ \\
\hline & $(-0.390)$ & $(-0.165)$ & $(-0.612)$ & $(-1.077)$ \\
\hline \multirow{2}{*}{$\begin{array}{l}\text { Belgium, } \\
22 / 03 / 2016\end{array}$} & $-3.240 \%$ & $-3.566 \%$ & $-1.487 \%$ & $-2.842 \%$ \\
\hline & $(-0.872)$ & $(-0.814)$ & $(-0.567)$ & $(-1.143)$ \\
\hline \multirow{2}{*}{$\begin{array}{l}\text { France, } \\
14 / 07 / 2016\end{array}$} & $1.475 \%$ & $2.086 \%$ & $0.611 \%$ & $0.316 \%$ \\
\hline & $(-0.242)$ & $(-0.336)$ & $\begin{array}{l}(0.202) \\
\end{array}$ & $(-0.143)$ \\
\hline \multirow{2}{*}{$\begin{array}{l}\text { Germany, } \\
19 / 12 / 2016\end{array}$} & $1.674 \%$ & $0.577 \%$ & $-0.559 \%$ & $-0.875 \%$ \\
\hline & $(1.147)$ & $(0.397)$ & $(-0.537)$ & $(-0.706)$ \\
\hline \multirow{2}{*}{$\begin{array}{l}\text { England, } \\
22 / 05 / 2017\end{array}$} & $-0.417 \%$ & $-1.745 \%$ & $0.773 \%$ & $-0.665 \%$ \\
\hline & $(-0.004)$ & $(-0.028)$ & $(0.003)$ & $(-0.009)$ \\
\hline \multirow{2}{*}{$\begin{array}{l}\text { England, } \\
03 / 06 / 2017\end{array}$} & $-1.923 \%$ & $-1.817 \%$ & $-0.523 \%$ & $-0.994 \%$ \\
\hline & $(-1.212)$ & $(-0.729)$ & $(-0.390)$ & $(-1.045)$ \\
\hline \multirow{2}{*}{$\begin{array}{l}\text { Spain, } \\
17 / 08 / 2017\end{array}$} & $-1.092 \%$ & $-0.720 \%$ & $-1.738 \% *$ & $-1.160 \%$ \\
\hline & $(-0.665)$ & $(-0.447)$ & $(-1.993)$ & $(-0.839)$ \\
\hline
\end{tabular}

*Statistically significant at $10 \%$; (Test values in parentheses); ${ }^{* *}$ Statistically significant at $5 \%$; ${ }^{* * *}$ Statistically significant at $1 \%$

If we look at the statistical significance, we can see that only the two attacks in Spain and the attack in England in 2005 led to statistically significant results. In Spain, in 2004, both the IBEX 35 index and the FTSE Euro 100 index continued to show the 
attacks' adverse effects, even after five days. Concerning the same attack, but considering the US index, we should note that the fact that the return remains negative is not significant (as opposed to the abnormal return on the day of the event), thus indicating that, after the first days of the event, this index witnessed a recovery. On the other hand, in the attack that occurred on August 17, 2017, in Spain, the significant negative abnormal return also indicates that the US index had not yet recovered from the attack's shock.

Table 3, which comprises the 11-day cumulative abnormal returns, the IBEX 35, and FTSE Euro 100 indices, also show significant negative values in the 2004 attack (Spain). We believe that the other statistically significant results are not related to the attacks because they do not correspond to either the event's day or the 5-day event window.

Table 3: 11-day cumulative abnormal returns $(\mathrm{t}=+10)$

\begin{tabular}{|c|c|c|c|c|}
\hline Events & $\begin{array}{l}\text { Domestic } \\
\text { Index }\end{array}$ & $\begin{array}{l}\text { FTSE } \\
\text { EURO } \\
100\end{array}$ & $\begin{array}{l}\text { S\&P } \\
500\end{array}$ & $\begin{array}{l}\text { Dow } \\
\text { Jones } \\
\text { Singapore }\end{array}$ \\
\hline \multirow{2}{*}{$\begin{array}{l}\text { Spain, } \\
11 / 03 / 2004\end{array}$} & $-5.053 \% *$ & $-5.025 \% *$ & $-2.091 \%$ & $-2.517 \%$ \\
\hline & $(-1.971)$ & $(-1.978)$ & $(-1.067)$ & $(-0.991)$ \\
\hline \multirow{2}{*}{$\begin{array}{l}\text { England, } \\
07 / 07 / 2005\end{array}$} & $-1.623 \%$ & $0.197 \%$ & $1.501 \%$ & $2.765 \% *$ \\
\hline & $(-1.088)$ & $(0.103)$ & (1.134) & $\begin{array}{l}(1.829) \\
\end{array}$ \\
\hline \multirow{2}{*}{$\begin{array}{l}\text { France, } \\
07 / 01 / 2015\end{array}$} & $9.176 \%$ & $7.399 \%$ & $0.331 \%$ & $2.742 \%$ \\
\hline & $(1.652)$ & $(1.334)$ & $(0.098)$ & $(1.470)$ \\
\hline \multirow{2}{*}{$\begin{array}{l}\text { France, } \\
13 / 11 / 2015\end{array}$} & $-2.097 \%$ & $-1.296 \%$ & $-0.698 \%$ & $-5.181 \%$ \\
\hline & $(-0.530)$ & $(-0.353)$ & $(-0.266)$ & $(-1.620)$ \\
\hline \multirow{2}{*}{$\begin{array}{l}\text { Belgium, } \\
22 / 03 / 2016\end{array}$} & $-6.394 \%$ & $-9.740 \%$ & $-3.998 \%$ & $-6.355 \% *$ \\
\hline & $(-1.271)$ & $(-1.643)$ & $(-1.127)$ & $(-1.889)$ \\
\hline \multirow{2}{*}{$\begin{array}{l}\text { France, } \\
14 / 07 / 2016\end{array}$} & $4.119 \%$ & $4.352 \%$ & $0.622 \%$ & $-2.322 \%$ \\
\hline & $(0.498)$ & $(0.517)$ & $(0.152)$ & $(-0.776)$ \\
\hline \multirow{2}{*}{$\begin{array}{l}\text { Germany, } \\
19 / 12 / 2016\end{array}$} & $2.679 \%$ & $1.646 \%$ & $0.286 \%$ & $0.867 \%$ \\
\hline & $(1.357)$ & $(0.836)$ & $(0.202)$ & $(0.517)$ \\
\hline \multirow{2}{*}{$\begin{array}{l}\text { England, } \\
22 / 05 / 2017\end{array}$} & $-1.119 \%$ & $-2.956 \%$ & $1.012 \%$ & $-0.575 \%$ \\
\hline & $(-0.544)$ & $(-0.891)$ & (0.682) & $(-0.437)$ \\
\hline \multirow{2}{*}{$\begin{array}{l}\text { England, } \\
03 / 06 / 2017\end{array}$} & $-2.972 \%$ & $-1.810 \%$ & $0.358 \%$ & $-1.439 \%$ \\
\hline & $(-1.383)$ & $(-0.536)$ & $(0.197)$ & $(-1.118)$ \\
\hline \multirow{2}{*}{$\begin{array}{l}\text { Spain, } \\
17 / 08 / 2017\end{array}$} & $-1.404 \%$ & $-0.601 \%$ & $-0.866 \%$ & $-0.785 \%$ \\
\hline & $(-0.631)$ & $(-0.275)$ & $(-0.733)$ & $(-0.419)$ \\
\hline
\end{tabular}

*Statistically significant at 10\%; (Test values in parentheses);

${ }^{* *}$ Statistically significant at $5 \%$; ${ }^{* * *}$ Statistically significant at $1 \%$

There are negative average abnormal returns in the three-event windows understudy concerning the analysis of the two-time horizons under study. However, these negative values are lower in time horizon 1, as shown in Figure 1. So, we confirm that the markets' resilience has been increasing over time, which can be partly explained by the greater stability of the market. The implementation of monetary measures and policies announced by the ECB may also explain the markets' current resilience following terrorist attacks.
Figure 1: Average returns in the event windows

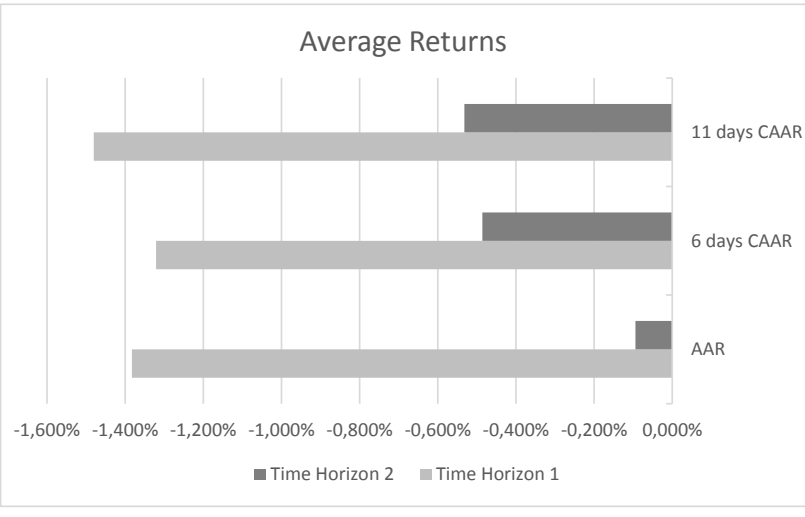

Regarding the transport sector, we found many discrepancies in the results. Sometimes, contrary to expectations, the sector reacted favorably (with positive returns) to the attacks. The abnormal returns for the day of the event, and the 6-day and 11-day cumulative abnormal returns are described in Table 4.

Table 4: Abnormal returns for the three-event windows (Dow Jones Transportation Index)

\begin{tabular}{|c|c|c|c|}
\hline Events & AR & $\begin{array}{l}\text { 6-day } \\
\text { CAR }\end{array}$ & $\begin{array}{l}11- \\
\text { day } \\
\text { CAR }\end{array}$ \\
\hline \multirow{2}{*}{$\begin{array}{l}\text { Spain, } \\
11 / 03 / 2004\end{array}$} & $0.561 \%$ & $3.260 \%$ & $4.640 \%$ \\
\hline & $(0.492)$ & $(1.168)$ & $(1.228)$ \\
\hline \multirow{2}{*}{$\begin{array}{l}\text { England, } \\
07 / 07 / 2005\end{array}$} & $0.026 \%$ & $4.402 \%$ ** & $7.970 \% *$ \\
\hline & $(0.034)$ & $(2.357)$ & $(3.151)$ \\
\hline \multirow{2}{*}{$\begin{array}{l}\text { France, } \\
07 / 01 / 2015\end{array}$} & $0.738 \%$ & $-0.029 \%$ & $5.238 \%$ \\
\hline & $(0.695)$ & $(-0.011)$ & (1.486) \\
\hline \multirow{2}{*}{$\begin{array}{l}\text { France, } \\
13 / 11 / 2015\end{array}$} & $0.361 \%$ & $1.714 \%$ & $0.644 \%$ \\
\hline & $(0.283)$ & $(0.548)$ & $(0.152)$ \\
\hline \multirow{2}{*}{$\begin{array}{l}\text { Belgium, } \\
22 / 03 / 2016\end{array}$} & $-1.301 \%$ & $-4.425 \%$ & $-9.656 \%$ ** \\
\hline & $(-1.125)$ & $(-1.563)$ & $(-2.519)$ \\
\hline \multirow{2}{*}{$\begin{array}{l}\text { France, } \\
14 / 07 / 2016\end{array}$} & $-0.147 \%$ & $0.799 \%$ & $0.473 \%$ \\
\hline & $(-0.090)$ & $(0.199)$ & $(0.087)$ \\
\hline \multirow{2}{*}{$\begin{array}{l}\text { Germany, } \\
19 / 12 / 2016\end{array}$} & $0.240 \%$ & $-5.101 \% * *$ & $-8.443 \%$ ** \\
\hline & $(0.258)$ & $(-2.242)$ & $(-2.740)$ \\
\hline \multirow{2}{*}{$\begin{array}{l}\text { England, } \\
22 / 05 / 2017\end{array}$} & $0.508 \%$ & $2.238 \%$ & $4.116 \%$ \\
\hline & $(0.528)$ & $(0.950)$ & $(1.290)$ \\
\hline \multirow{2}{*}{$\begin{array}{l}\text { England, } \\
03 / 06 / 2017\end{array}$} & $-0.092 \%$ & $1.638 \%$ & $3.426 \%$ \\
\hline & $(-0.095)$ & $(0.688)$ & (1.063) \\
\hline \multirow{2}{*}{$\begin{array}{l}\text { Spain, } \\
17 / 08 / 2017\end{array}$} & $-2.176 \%$ ** & $-2.370 \%$ & $2.131 \%$ \\
\hline & $(-2.348)$ & $(-1.044)$ & $(0.693)$ \\
\hline
\end{tabular}

"Statistically significant at 10\%; (Test values in parentheses); ${ }^{* *}$ Statistically significant at $5 \% ;{ }^{* * *}$ Statistically significant at $1 \%$

In the attack that occurred in Spain in 2004, we expected the index understudy returns to be negative (and significant) since this attack had led to significant negative returns in the stock market indices under study. Furthermore, the target of the attack in question was the public transport system in central Madrid and, consequently, the transport sector would be expected to react negatively to the 
attack. Compared to the attack in London (England) in 2005, the cumulative abnormal returns for both estimation windows are positive and statistically significant. Once again, we expected negative returns given the attack (explosions in the London public transport system).

The other significant results are negative and relate to attacks that occurred in Belgium (2016), Germany (2016), and Spain (2017). However, not all indices show negative returns. These attacks are directly or indirectly associated with the transport sector.

\section{Conclusion}

This study presents impressive results by concluding that there are no patterns associated with the impact of a terrorist attack on capital markets, contrary to what common sense would lead us to expect. We noted that the results obtained for specific events that had already been studied (for example, the cases of Johnston and Nedelescu [1] and Bonekamp and Veen [12]) are similar to the ones obtained in this study, thus corroborating the conclusions we drew. However, the most important contribution we can draw from our study is that capital markets tend to become more resilient to terrorist attacks over time, confirming the work developed by Chen and Siems [7].

We fulfilled the objective of analysing the attacks that occurred in the European Union, between 2015 and 2017, which resulted in 8 or more fatalities and the attacks that occurred in Madrid and London, in 2004 and 2005, respectively. The analysis of abnormal returns on the date of the events under analysis, allowed us to ascertain which events were responsible for creating a certain impact on the capital market, which direction of that impact and how long it would take. Those are our contribution to expand scientific knowledge on this matter.

In short, there is no evidence that the development of the indices is affected after the attacks. Despite the growth of terrorism in the European Union in recent years, (significant) negative abnormal returns are increasingly scarce, thus indicating that the attacks' effects have diminished as their numbers have increased. This means that investors have learned to cope with external shocks such as terrorist attacks and, as a result, markets are becoming more resilient. Some of the results obtained in this study align with the efficient market hypothesis, which states that markets quickly reflect all relevant information. Our evidence of scarce abnormal returns for long and recurrent periods following terrorism events, suggests financial markets alignment with Fama et al. [13] research related to market efficiency.

For future research, different methodologies can be used, such as the generalized autoregressive conditional heteroscedasticity (GARCH) model combined with the extreme value theory (EVT) used by Chesney [2], or linear regression. These methodologies used together could reinforce the results obtained through the event study methodology. Another interesting test to be done would be the quantification of the transactions that occurred after the terrorist attacks. An increase in the number of transactions could indicate that individual investors could be selling their shares, which are being bought by large companies at a lower price. It is also important to analyze other regions (e.g. Middle East) and different sectors not covered in this study.

\section{References:}

[1] Johnston, R. Berry, and Oana Nedelescu, The Impact of Terrorism on Financial Market, Washington: International Monetary Fund, 2005.

https://www.imf.org/external/pubs/ft/wp/2005/ wp0560.pdf

[2] Chesney, Marc, Ganna Reshetar, and Mustafa Karaman, The impact of terrorism on financial markets: An empirical study, Journal of Banking \& Finance 35 (2), 2011, pp. 253-267. http://www.sciencedirect.com/science/article/pi i/S0378-4266(10)00292-X

[3] Cam, Marie-Anne, "The Impact of Terrorist Attacks on Financial Markets." Ph.D. Thesis, RMIT University, Melbourne, 2007. http://adt.lib.rmit.edu.au/adt/public/adtVIT20080731.102528

[4] Enders, Walter, and Eric Olson, Measuring the economic costs of terrorism. Tuscaloosa: Department of Economics Finance and Legal Studies, University of Alabama, 2012. https://www.socsci.uci.edu/ mrgarfin/OUP/pap ers/Enders.pdf

[5] Becker, Gary, and Yona Rubenstein, Fear and Response to Terrorism: An economic analysis. Chicago: Department of Economics, University of Chicago, 2004. https://EconPapers.repec.org/RePEc:cep:cepdp s:dp1079.

[6] Taylor, Brain, The Historical Impact of Crisis on Financial Markets, Global Financial Data, 2004. www.globalfinancialdata.com

[7] Chen, Andrew, and Thomas Siems, The effects of terrorism on global capital markets. 
European Journal of Political Economy 20 (2), 2004, pp.

349-366. http://www.sciencedirect.com/science/article/pi i/S0176-2680(03)00102

[8] Ferguson, Roger, "September 11, the Federal Reserve, and the financial system.", BIS Review 5, Vanderbilt University, Nashville, Tennessee, 2003. https://www.bis.org/review/r030207d.pdf

[9] Cam, Marie-Anne, "The impact of terrorism on United States Industries." Economic Papers, 27(2), 2008, pp. 115-134. https://doi.org/10.1111/j.1759-

3441.2008.tb01031.x

[10] Apergis, Emmanuel, and Nicholas Apergis, "The 11/13 Paris terrorist attacks and stock prices: The case of the International defense industry." Finance Research Letters 17, 2016, pp. 186-192. doi.org/10.1016/j.frl.2016.03.002

[11] Aliyev, Vasif, "The Role of the Struggle against Terrorism in Tourism Development in Azerbaijan", WEAS Transportation on Environment and Development, ISSN/E-ISSN: 1790-5079, 2224-3496, 16, 2020, Art. 47, 464470.

[12] Bonekamp, Bas, and Tom Veen, "Terrorist Attacks and Financial Markets.", CESifo Working Paper No. 6324, Munique, 2017. http://hdl.handle.net/10419/155566

[13] Fama, Eugene, Lawrence Fisher, Michael Jensen, and Richard Roll, "The adjustment of stock prices to new information.", International Economic Review 10, 1969, pp. 1-21. DOI: $10.2307 / 2525569$

[14] Schwert, G. W. (1981). Using financial data to measure effects of regulation. Journal of Law and Economics 24, 124-58.

[15] Campbell, John, Andrew Lo, and A. Craig Mackinlay, The econometrics of financial markets. New Jersey: Second printing at Princeton University Press, 1997. ISBN: 9780691043012

[16] Brown, Stephen, and Jerold Warner, "Using daily stock returns: the case of event studies.", Journal of Financial Economics 14, 1985, pp. 3-31.https://doi.org/10.1016/0304-

405X(85)90042-X

\section{Contribution of individual authors to the creation of a scientific article (ghostwriting policy)}

All the authors contributed equally in the development of the present paper. All of the phases of the paper development proper have been discussed and worked on by the authors. All authors have read and agreed to the published version of the manuscript.

\section{Sources of funding for research presented in a scientific article or scientific article itself}

The project is funded under the program of the Minister of Science and Higher Education titled "Regional Initiative of Excellence" in 2019-2022, project number $018 / \mathrm{RID} / 2018 / 19$, the amount of funding PLN 10788 423,16 and also by the Portuguese national funds through FCT - Fundação para a Ciência e a Tecnologia, I.P., project number UIDB/00685/2020

\section{Creative Commons Attribution License 4.0 (Attribution 4.0 International, CC BY 4.0)}

This article is published under the terms of the Creative Commons Attribution License 4.0 https://creativecommons.org/licenses/by/4.0/deed.en US 